\title{
Antibody response of brown trout Salmo trutta injected with pathogenic Saprolegnia parasitica antigenic extracts
}

\author{
J. M. Fregeneda-Grandes, F. Rodríguez-Cadenas, \\ M. T. Carbajal-González, J. M. Aller-Gancedo* \\ Departamento de Sanidad Animal, Facultad de Veterinaria, Universidad de León, 24071 León, Spain
}

\begin{abstract}
Brown trout Salmo trutta injected with antigenic extracts from a pathogenic isolate of Saprolegnia parasitica developed specific antibodies that were detected by enzyme-linked immunosorbent assay (ELISA), immunofluorescence (IF) and Western blotting (WB), but not by immunodiffusion (ID). Three groups of five 2 yr old brown trout were injected intraperitoneally with 3 different antigenic extracts: small hyphal fragments (HF) and soluble extracts from sonicated mycelia grown in medium with or without $\beta$-sytosterol (SEB and SE, respectively). In the 2 groups injected with SE and SEB, antibodies were found in $66.7 \%$ of the serum samples by ELISA, $54.5 \%$ by IF and $48.5 \%$ by WB. In the group injected with HF, only 1 trout survived the experiment, and in this fish only 1 sample was positive by ELISA. The results obtained by ELISA and IF were similar and show that there is cross-reaction between the antigens used. By WB, the proteins most frequently recognised were 2 proteins of 25 and $29 \mathrm{kDa}$. No significant differences were found in the groups injected with SE or SEB.
\end{abstract}

KEY WORDS: Saprolegnia parasitica $\cdot$ Brown trout $\cdot$ Antibody response $\cdot$ Immunological techniques

\section{INTRODUCTION}

Saprolegniosis caused by Saprolegnia species is an important freshwater fish disease, which often affects wild and farmed salmonids. In salmonid fish farms, saprolegniosis mainly affects broodfish and incubating eggs, causing major financial losses (Pickering \& Willoughby 1982, Noga 1993, Bruno \& Wood 1999). The disease appears as cotton-wool-like tufts on the body surface causing destruction of the skin and/or fins due to cellular necrosis by hyphal penetration that is generally restricted is to the epidermis and dermis. Once infected, fish do not recover unless treated, and death occurs due to osmoregulatory failure caused by destruction of the superficial tissues (Pickering \& Willoughby 1982, Hatai \& Hoshiai 1994).

It is thought that an important defence mechanism of fish against saprolegniosis is the mucus layer of the epidermis, which acts as a physical barrier, and inter- nal cellular responses based on non-specific phagocytic activity of inflammatory cells; it is, however, uncertain whether the specific immune response is involved (Hodkinson \& Hunter 1970, Sohnle \& Chusid 1983, Wood et al. 1986, Pickering 1994). Recently, Szalai et al. (1994) have suggested that reduced levels of a humoral factor (phosphorylcholine-reactive protein, PRP) play an important role in increasing the susceptibility of channel catfish Ictalurus punctatus to infection by Saprolegnia spp. Moreover, Thompson et al. (1997) have shown an antibody response by snakehead Channa striata to Aphanomyces invaderis, another important oomycete fish pathogen. However, knowledge about the production of specific antibodies against Saprolegnia infection in fish, particularly in brown trout Salmo trutta, is scarce, and the results are contradictory, depending on the species studied, water temperature and the antigens and serological techniques used (Hodkinson \& Hunter 1974, El-Feki 1987, 
Sohnle \& Chusid 1983, Bly et al. 1993). Hodkinson \& Hunter (1974) investigated the influence of culture conditions on the antigenic products of Saprolegnia and found that precipitating reactions only occurred between salmon serum and antigens from Saprolegnia grown in medium containing $\beta$-sytosterol.

The aim of the present research was to study the capacity of brown trout injected with antigenic extracts of Saprolegnia parasitica pathogenic to salmonids to produce specific serum antibodies.

\section{MATERIALS AND METHODS}

Fish and antigenic extracts. Three different groups of five $2 \mathrm{yr}$ old brown trout $(225 \pm 70 \mathrm{~g}$ weight and $26.5 \pm 2.8 \mathrm{~cm}$ length) were injected intraperitoneally with $0.2 \mathrm{ml}$ of antigenic extracts in phosphatebuffered saline (PBS) (approximately $200 \mu \mathrm{g}$ of total protein) twice at 2 wk intervals. The extracts were mixed with Freund's complete adjuvant at a ratio of 3:1 in the first injection and with Freund's incomplete adjuvant (1:1) in the second injection. A fourth group was injected only with PBS and adjuvant as a negative control group. Three different antigenic extracts were prepared using the pathogenic isolate TRU 8 of Saprolegnia parasitica (formerly Saprolegnia sp.; Fregeneda-Grandes et al. 2000, 2003): (1) small hyphal fragments (HF) obtained after sonication of formalised-mycelial mats growing on glucose-yeast broth (GY: $1 \%$ glucose, $0.25 \%$ yeast extract); (2) soluble extract (SE) from sonicated formalised-mycelia growing on GY; and (3) SE from sonicated formalisedmycelia growing on GY supplemented with $20 \mathrm{mg} \mathrm{l}^{-1}$ of $\beta$-sytosterol (SEB). The experiment was carried out between April and June 2004 at a fish farm in small raceways situated in the open and with a continuous supply of well water. The water temperature varied from 9 to $14^{\circ} \mathrm{C}$. Two wk after the second injection, blood samples were obtained by puncturing the caudal vein of all surviving fish 4 times at $2 \mathrm{wk}$ intervals. Fish were anaesthetised with $50 \mathrm{mg} \mathrm{l}^{-1}$ of MS 222 (tricaine methane sulphonate). After clotting overnight at $4^{\circ} \mathrm{C}$, the blood samples were centrifuged at $1000 \mathrm{~g}$ for $45 \mathrm{~min}$ to obtain the serum. The sera were stored at $-20^{\circ} \mathrm{C}$ until use.

Antibody detection. The presence of antibodies in the serum was analysed by enzyme-linked immunosorbent assay (ELISA), immunodiffusion (ID) and Western blotting (WB) using SE and by immunofluorescence (IF) with HF extract. In all these techniques mouse or rabbit polyclonal antiserum (obtained after immunisation with HF or SE antigens) and a preimmune serum were used as positive and negative controls, respectively.
ELISA was performed in 96-well polystyrene plates (Costar, Corning), which were coated with SE diluted in PBS $\left(20 \mu \mathrm{g} \mathrm{ml}^{-1}\right)$ overnight at $4^{\circ} \mathrm{C}$ and blocked with PBS plus $1 \%$ of bovine serum albumin (PBS$\mathrm{BSA})$ for $1 \mathrm{~h}$ at $37^{\circ} \mathrm{C}$. Serial 2-fold dilutions (1:20 to 1:2560) of trout serum in PBS-BSA were added and incubated for $3 \mathrm{~h}$ at room temperature; then the plates were washed 3 times with PBS plus $0.05 \%$ Tween-20. The plates were then incubated for $1 \mathrm{~h}$ at room temperature with anti-rainbow trout IgM monoclonal antibody (Mab 4C10) (Thunvander et al. 1990) diluted 1:1000 in PBS-BSA; a further washing cycle was carried out and the plates were incubated for $1 \mathrm{~h}$ at room temperature with anti-mouse immunoglobulins conjugated with peroxidase (Sigma-Aldrich) diluted 1:1000 in PBS-BSA. After a final washing step, OPD substrate (DakoCytomation) was added, and the reaction was stopped after $15 \mathrm{~min}$ at room temperature by addition of $0.5 \mathrm{M} \mathrm{H}_{2} \mathrm{SO}_{4}$. Optical density (OD) was measured at $492 \mathrm{~nm}$, and ELISA titre was defined as a reciprocal value of the highest serum dilution giving an OD value $>0.5$ (mean OD values of the negative control sera plus 3 times the standard deviation). Only titres of 40 or higher were considered positive.

ID was performed on microscope slides, which were coated with $4 \mathrm{ml}$ of $1 \%$ veronal-buffered agarose (Pronadisa-Hispanlab). Groups of 7 holes (1 central and 6 peripheral) of $3 \mathrm{~mm}$ diameter were cut in the gel. Various distances between neighbouring holes and dilutions of SE and trout sera were used in different experiments. Holes were filled with $12 \mu \mathrm{l}$ of antigen or serum dilution, and the slides were incubated in a wet chamber for 24 to $72 \mathrm{~h}$. Following incubation, the slides were washed first with $5 \%$ sodium citrate for $1 \mathrm{~h}$, then with PBS for $24 \mathrm{~h}$ and finally with distilled water for $2 \mathrm{~h}$. Slides were then stained with Coomassie Brillant Blue R-250 (Bio-Rad).

WB analysis was performed in order to identify individual proteins of SE recognised by the trout sera. Purification of SE, SDS-PAGE and sample transfer to nitrocellulose membranes were made as described by Lilley et al. (1997), except that Proteinase $\mathrm{K}$ solution was not used and protein concentration was determined by Branford's method and adjusted to $1 \mathrm{mg} \mathrm{ml}^{-1}$. Following transfer, the nitrocellulose membrane was washed with distilled water for $5 \mathrm{~min}$ and then blocked with $5 \%$ dry skimmed milk in tris-buffered saline (TBS). After washing 3 times for 5 min with TBS, the nitrocellulose membranes were cut into strips of $3 \mathrm{~mm}$ width. Trout sera diluted 1:20 in TBS were added and incubated for $3 \mathrm{~h}$ at room temperature. After a further washing cycle, the strips were incubated for $1 \mathrm{~h}$ at room temperature with MAb 4C10, followed by washing 
3 times with TBS and incubation for $1 \mathrm{~h}$ at room temperature with anti-mouse immunoglobulins conjugated with peroxidase (Sigma-Aldrich) diluted 1:1000 in TBS. After a final washing step, the bands reacting with the sera were visualised with 4-chloro-1naphthol (Sigma-Aldrich) and the reaction was stopped with distilled water.

For IF, $20 \mu \mathrm{l}$ of HF extract was added to each well of IF slides (bioMérieux), allowed to dry in a laminar flow cabinet and fixed with acetone for $10 \mathrm{~min}$. Thereafter, $15 \mu$ l of serial 2-fold dilutions (from 1:4 to 1:64) of trout serum in PBS was placed in each well. The slides were incubated in a wet chamber for $3 \mathrm{~h}$ at room temperature and then washed 3 times with PBS. Then, $15 \mu \mathrm{l}$ of Mab 4C10 was added to each well for $1 \mathrm{~h}$ at room temperature, the slides were washed again and $15 \mu \mathrm{l}$ of anti-mouse immunoglobulins conjugated with fluorescein isothiocyanate, FICT (SigmaAldrich) diluted 1:80 in PBS was added to each well for $1 \mathrm{~h}$ at $37^{\circ} \mathrm{C}$. The slides were washed again, allowed to dry and finally observed under a Nikon Eclipse E 400 fluorescence microscope. Wells were considered positive if the hyphal fragments emitted a bright, apple-green fluorescence. Only titres of 8 or higher were considered positive.

\section{RESULTS}

The results obtained in the present work are shown in Table 1. In the 2 groups of trout Salmo trutta injected with SE and SEB, antibodies were found in $66.7 \%$ of the serum samples (22 out of 33 ) by ELISA, $54.5 \%$ (18 out of 33) by IF and $48.5 \%$ (16 out of 33 ) by WB. All the samples were negative by ID. In these 2 groups the antibody titres varied from 40 to 640 in ELISA and from 8 to 64 in IF. In WB, trout sera recognised 1 to 8 bands (out of the 28 bands of SE), and the bands most frequently recognised were 2 proteins of 25 and $29 \mathrm{kDa}$ (Fig. 1). In the group injected with HF extract, only 1 trout survived the experiment. In this fish, only the sample taken in the sixth week was positive by ELISA, with a low titre of 40 . All the samples from the control group were negative by all the techniques used. The results obtained using the different techniques were similar, except for ID, and show that there is crossreaction between the antigenic extracts used. However, the greatest number of positive samples was detected by ELISA, followed by IF and finally by WB. A direct relationship was also found between the number of bands recognised in WB and the ELISA or IF titre of the serum samples.

Table 1. Detection of anti-Saprolegnia serum antibodies by enzyme-linked immunosorbent assay (ELISA), immunofluorescence (IF), Western blotting (WB) and immunodiffusion (ID) in brown trout Salmo trutta injected with antigenic extracts of Saprolegnia parasitica pathogenic to salmonids. SE: trout injected with soluble extract; SEB: trout injected with soluble extract obtained in medium with $\beta$-sytosterol; HF: trout injected with hyphal fragments; NC: negative control, trout not injected; in ELISA: - (negative) is titre $\leq 20$; in IF: - (negative) is titre $\leq 4$; NS: non-surviving trout

\begin{tabular}{|c|c|c|c|c|c|c|c|c|c|c|c|c|c|c|c|c|}
\hline \multirow[t]{2}{*}{ Trout } & \multicolumn{4}{|c|}{$\begin{array}{l}2 \text { wk after } \\
\text { immunisation }\end{array}$} & \multicolumn{4}{|c|}{$\begin{array}{c}4 \text { wk after } \\
\text { immunisation }\end{array}$} & \multicolumn{4}{|c|}{$\begin{array}{c}6 \text { wk after } \\
\text { immunisation }\end{array}$} & \multicolumn{4}{|c|}{$\begin{array}{l}8 \text { wk after } \\
\text { immunisation }\end{array}$} \\
\hline & $\begin{array}{l}\text { ELISA } \\
\text { (titre) }\end{array}$ & $\begin{array}{c}\text { IF } \\
\text { (titre) }\end{array}$ & WB & ID & $\begin{array}{l}\text { ELISA } \\
\text { (titre) }\end{array}$ & $\begin{array}{c}\mathrm{IF} \\
\text { (titre) }\end{array}$ & WB & ID & $\begin{array}{l}\text { ELISA } \\
\text { (titre) }\end{array}$ & $\begin{array}{c}\text { IF } \\
\text { (titre) }\end{array}$ & WB & ID & $\begin{array}{l}\text { ELISA } \\
\text { (titre) }\end{array}$ & $\begin{array}{c}\text { IF } \\
\text { (titre) }\end{array}$ & WB & ID \\
\hline SE-1 & $+(40)$ & - & + & - & $+(40)$ & - & + & - & $+(80)$ & $+(16)$ & + & - & $+(160)$ & $+(64)$ & + & - \\
\hline SE-2 & $+(160)$ & $+(32)$ & + & - & $+(640)$ & $+(64)$ & + & - & NS & NS & NS & NS & NS & NS & NS & NS \\
\hline SE-3 & - & - & - & - & $+(40)$ & $+(8)$ & - & - & $+(40)$ & $+(8)$ & - & - & - & - & - & - \\
\hline SE-4 & - & - & - & - & $+(80)$ & $+(16)$ & + & - & $+(40)$ & - & + & - & $+(40)$ & - & - & - \\
\hline SE-5 & NS & NS & NS & NS & NS & NS & NS & NS & NS & NS & NS & NS & NS & NS & NS & NS \\
\hline SEB-1 & - & $+(8)$ & - & - & $+(40)$ & $+(8)$ & + & - & $+(40)$ & $+(8)$ & - & - & - & - & - & - \\
\hline SEB-2 & - & - & - & - & $+(80)$ & $+(16)$ & + & - & $+(40)$ & - & - & - & NS & NS & NS & NS \\
\hline SEB-3 & - & - & - & - & - & - & - & - & - & - & - & - & - & - & - & - \\
\hline SEB-4 & - & - & - & - & $+(80)$ & $+(16)$ & + & - & $+(80)$ & $+(16)$ & + & - & $+(40)$ & $+(8)$ & + & - \\
\hline SEB-5 & $+(40)$ & $+(8)$ & - & - & $+(640)$ & $+(32)$ & + & - & $+(640)$ & $+(32)$ & + & - & $+(320)$ & $+(32)$ & + & - \\
\hline HF-1 & - & - & - & - & NS & NS & NS & NS & NS & NS & NS & NS & NS & NS & NS & NS \\
\hline $\mathrm{HF}-2$ & NS & NS & NS & NS & NS & NS & NS & NS & NS & NS & NS & NS & NS & NS & NS & NS \\
\hline $\mathrm{HF}-3$ & - & - & - & - & - & - & - & - & $+(40)$ & - & - & - & - & - & - & - \\
\hline $\mathrm{HF}-4$ & - & - & - & - & NS & NS & NS & NS & NS & NS & NS & NS & NS & NS & NS & NS \\
\hline HF-5 & NS & NS & NS & NS & NS & NS & NS & NS & NS & NS & NS & NS & NS & NS & NS & NS \\
\hline NC-1 & - & - & - & - & NS & NS & NS & NS & NS & NS & NS & NS & NS & NS & NS & NS \\
\hline NC-2 & - & - & - & - & - & - & - & - & - & - & - & - & - & - & - & - \\
\hline NC-3 & - & - & - & - & - & - & - & - & - & - & - & - & - & - & - & - \\
\hline NC-4 & - & - & - & - & - & - & - & - & - & - & - & - & - & - & - & - \\
\hline NC-5 & - & - & - & - & - & - & - & - & - & - & - & - & - & - & - & - \\
\hline
\end{tabular}




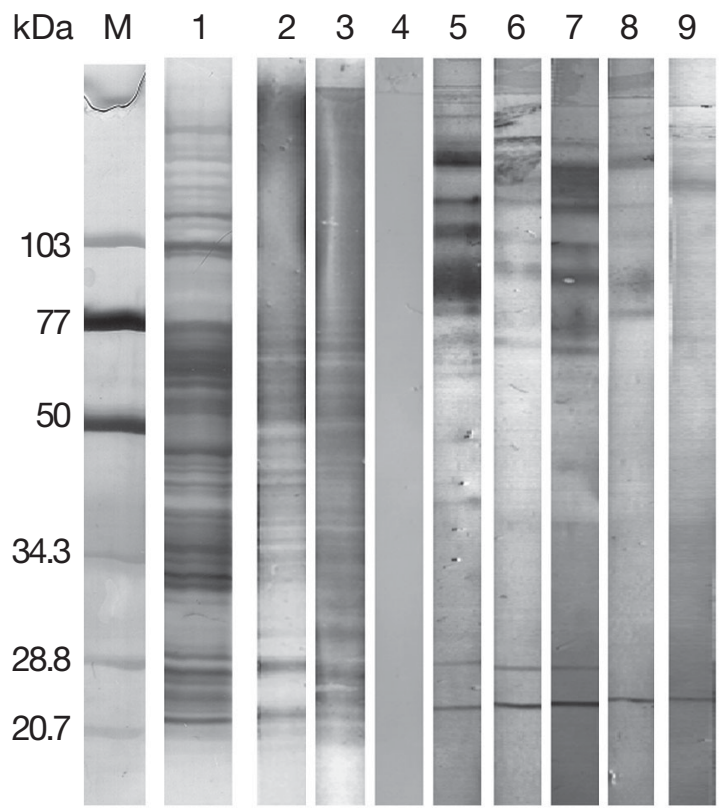

Fig. 1. Western blot on nitrocellulose membrane after SDSPAGE (Gel 4 to 20\%) of Saprolegnia parasitica soluble extract. Lane M: low-range molecular weight protein marker (Bio-Rad, Cat. No. 161-0304); Lane 1: silver-stained SDSPAGE of soluble extract, $\mathrm{SE}_{i}$ Lane 2: rabbit polyclonal positive serum; Lane 3: mouse polyclonal positive serum; Lane 4:

negative trout serum; Lanes 5 to 9: positive trout sera

\section{DISCUSSION}

The results obtained by other authors in relation to the detection of anti-Saprolegnia serum antibodies are contradictory. Thus, El-Feki (1987) did not find any serological response in carp intraperitoneally injected with soluble or hyphal extracts of $S$. diclina or in carp experimentally infected with $S$. diclina, but did detect antibodies in rainbow trout with saprolegniosis from a fish farm. Moreover, Sohnle \& Chusid (1983) and Bly et al. (1993) did not find precipitating antibodies in rainbow trout or channel catfish, respectively, experimentally inoculated with Saprolegnia sp. However, Hodkinson \& Hunter (1970) found antibodies in $93 \%$ of the wild salmon studied, but only $66 \%$ of these were colonised by Saprolegnia sp. In all these studies, the technique used was a double-diffusion immunoprecipitation test. In the present study no positive sample was found by ID in the immunised brown trout. However, when ID was performed using serum samples from mice and rabbit immunised with HF or SE, several positive samples were found (and used as positive controls). These findings may reflect differences in the immune response against Saprolegnia sp. antigens between fish and mice or rabbit. Thus, in WB analysis, we found that mice and rabbit sera recognised more proteins (17 to 18 ) than trout sera (1 to 8).
In contrast to the results obtained by Hodkinson \& Hunter (1974), no significant differences were found when using soluble extracts from culture media with or without $\beta$-sytosterol. The response to SE and SEB may be better than to HF extract, although it is difficult to prove in our study because only 1 trout survived $4 \mathrm{wk}$ in the group immunised with the HF antigen. $\beta$-glucans are one of the major components of the Oomycetes hyphal wall. Moreover, $\beta$-glucans have been shown to stimulate non-specific immunity in fish such as lysozyme, complement activity and phagocytic activation (Robertsen et al. 1994), which may be involved in the immune response of fish to fungal infections. Thus, Álvarez et al. $(1988,1995)$ found increased phagocytic activity in macrophages, but also in the sinusoidal endothelial cells of the peripheral lymphoid organs (spleen, kidney and thymus) of Saprolegnia-infected wild brown trout. In some cytoplasmic vesicles of these cells they also found an electro-dense content that may represent components of the fungal wall. They speculated that the hypertrophic aspect and degeneration of the endothelial cells observed in the lymphoid organs of sick trout would appear to indicate a possible toxic effect of this material. These findings may explain the high mortality rate observed in the current study in the group of trout injected with HF extract.

In conclusion, the present work has shown that brown trout injected with antigenic extracts from a pathogenic isolate of Saprolegnia parasitica developed specific antibodies that can be detected by standard immunological techniques. These are initial experiments, so further studies will be necessary, involving a greater number of serum samples from fish infected both experimentally and naturally with Saprolegnia for a better understanding of the specific immune response against Saprolegnia infections. These studies will include characterisation of the more antigenic proteins of Saprolegnia extracts and their usefulness for fish vaccination.

Acknowledgements. This work formed part of the research project AGL2002-00505 financed by the Spanish Ministry of Science and Technology (Ministerio de Ciencia y Tecnología) and co-financed by the European Regional Development Fund (ERDF). F.R.C. and M.T.C.G. were funded by this project. We are likewise grateful to the Local Environmental Service for Leon of the Regional Government of Castile and Leon (Servicio Territorial de Medio Ambiente de León, Junta de Castilla y León) for providing the fish and facilities and to the EU Reference Laboratory for Fish Diseases (Aarhus, Denmark) for the anti-rainbow trout IgM monoclonal antibody.

\section{LITERATURE CITED}

Álvarez F, Razquin B, Villena A, López-Fierro P, Zapata A (1988) Alterations in the peripheral lymphoid organs and differential leukocyte counts in Saprolegnia-infected 
brown trout, Salmo trutta fario. Vet Immunol Immunopathol 18:181-193

Álvarez F, Villena A, Zapata A, Razquin B (1995) Histopathology of the thymus in Saprolegnia-infected wild brown trout, Salmo trutta L. Vet Immunol Immunopathol 47: 163-172

Bly JE, Lawson LA, Abdel-Aziz ES, Clem LW (1993) Channel catfish, Ictalurus punctatus, immunity to Saprolegnia sp. J Appl Aquac 3:35-50

Bruno DW, Wood BP (1999) Saprolegnia and other Oomycetes. In: Woo PTK, Bruno DW (eds) Fish diseases and disorders, Vol 3: Viral, bacterial and fungal infections. CABI Publishing, Wallingford, p 599-659

El-Feki MA (1987) Studies on the host-parasite interaction between carp and Saprolegnia. PhD thesis. University of Aston, Birmingham

Fregeneda-Grandes JM, Fernández-Díez M, Aller-Gancedo JM (2000) Ultrastructural analysis of Saprolegnia secondary zoospore cyst ornamentation from infected wild brown trout, Salmo trutta L., and river water indicates two distinct morphotypes amongst long-spined isolates. J Fish Dis 23:147-160

Fregeneda-Grandes JM, Fernández-Díez M, Aller-Gancedo JM (2003) Ultrastructural analysis of Saprolegnia secondary zoospore cyst ornamentation from infected wild brown trout, Salmo trutta L., and river water indicates two distinct morphotypes amongst long-spined isolates. J Fish Dis 26:314 (Erratum)

Hatai K, Hoshiai G (1994) Pathogenicity of Saprolegnia parasitica Cocker. In: Mueller GJ (ed) Salmon saprolegniosis. US Department of Energy, Bonneville Power Administration, Portland, OR, p 87-98

Hodkinson M, Hunter A (1970) Immune response of U.D.N.infected salmon to Saprolegnia. J Fish Biol 2:305-311

Hodkinson M, Hunter A (1974) The influence of culture conditions on the antigenic products of Saprolegnia. Mycopathol Mycol Appl 52:133-140

Editorial responsibility: David Bruno,

Aberdeen, UK
Lilley JH, Thompson KD, Adams A (1997) Characterization of Apahanomyces invadans by electrophoretic and Western blot analysis. Dis Aquat Org 30:187-197

Noga EJ (1993) Water mold infections of freshwater fish: recent advances. Annu Rev Fish Dis 3:291-304

Pickering AD (1994) Factors which predispose salmonid fish to saprolegniasis. In: Mueller GJ (ed) Salmon saprolegniasis. US Department of Energy, Bonneville Power Administration, Portland, OR, p 67-86

Pickering AD, Willoughby LG (1982) Saprolegnia infections of salmonid fish. In: Roberts RJ (ed) Microbial diseases of fish. Academic Press, London, p 271-297

Robertsen B, Engstad R, Jørgensen JB (1994) $\beta$-glucans as immunostimulants in fish. In: Stolen J, Fletcher TC (eds) Modulators of fish immune response. SOS Publications, Fair Haven, NJ, p 83-99

Sohnle PG, Chusid MJ (1983) Defence against infection with filamentous fungi in rainbow trout. Comp Biochem Physiol A 74:71-76

Szalai AJ, Bly JE, Clem LW (1994) Changes in serum concentration of channel catfish (Ictalurus punctatus Rafinesque) phosphorylcholine-reactive protein (PRP) in response to inflammatory agents, low-temperature shock and infection by the fungus Saprolegnia sp. Fish Shellfish Immunol $4: 323-336$

Thompson KD, Lilley JH, Chinabut S, Adams A (1997) The antibody response of snakehead, Channa striata Bloch, to Aphanomyces invaderis. Fish Shellfish Immunol 7: 349-353

Thunvander A, Fossum C, Lorenzen N (1990) Monoclonal antibodies to salmonid immunoglobulin: characterization and applicability in immunoassays. Dev Comp Immunol 14:415-423

Wood SW, Willoughby LG, Beakes GW (1986) Preliminary evidence for inhibition of Saprolegnia fungus in the mucus of brown trout, Salmo trutta L., following experimental challenge. J Fish Dis 9:557-560

Submitted: July 31, 2006; Accepted: November 30, 2006

Proofs received from author(s): February 12, 2007 